\title{
Differential Unmet Need for Family Planning: A Study of Uttar Pradesh, India
}

\author{
Prof. M S R Murthy \\ Emeritus Professor (Retired), Department of Population Studies, Sri Venkateswara University, 15-57/4 Padmavathinagar \\ Tirupati-517502, Andhra Pradesh, India
}

\begin{abstract}
Unmet need for family planning has been the major impediment in regulating fertility in developing countries. Unmet need arises out of knowledge, awareness about availability, accessibility and affordability of family planning methods: for spacing and for limiting. The present study has concentrated on the most populous state of Uttar Pradesh state of India. Data has been taken from the District Level Household Survey (2005). Correspondence analysis has been used to see the unmet need for spacing and limiting methods of family planning. Some districts in the central part of Uttar Pradesh have greater need for family planning. Certain developed districts too have unmet need for spacing methods of family planning. Two districts had lowest unmet need for spacing: Kanpur Nagar (3.11), Gautam Buddha Nagar (4.45). These two districts are well developed. There are two peaks of unmet need for spacing in the state: one group: Shahjahanpur, Kheri, Sitapur and Hardoi and the other: Sultanpur, Bahraich, Sharwasti, Balarampur, Gonda and Siddarthanagar. The state as a whole has a low unmet need (10.07 per cent) for spacing methods of family planning. On the other hand around one-fifth (20.64 per cent) state has an unmet need for limiting methods. Some of the districts like, Jhansi (7.31), Varanasi (8.8) and Sonbhadra (9.7) have lowest unmet need for limiting the family size. On the other hand nine districts like, Fatehpur (25.48), Hardoi (26.25), Auraiya (26.35), Balrampur (26.55), Etawah (27.08), Agra (28.63), Etah (29.5), Budaun (31.23), Ferozabad (33.49) have highest unmet need for limiting. Gautam Buddha Nagar was one of the districts with low unmet need (14. 89 per cent) for limiting methods along with spacing method (4.45 per cent) while Kanpur too has low (17.44) unmet need for limiting. Varanasi district has low unmet need for spacing (8.8) as well as limiting methods (8.96) of family planning. Jhansi district too has low unmet need (5.21) for spacing as well as for limiting (7.31) methods. The other districts were Sonbhadra (spacing: 8.47 and limiting: 9.7), Jalaun (spacing: 5.04; limiting: 11.46). The discussion was based on the development of districts (wealth index) in relation to spacing and limiting methods of family planning. Well developed districts had unmet need concentrated at rich level while it was concentrated at low level of wealth index with undeveloped districts.
\end{abstract}

Keywords: Correspondence analysis, logistic regression, wealth index, outcome of pregnancy, unmet need for family planning

\section{Introduction}

Unmet need for family planning arises out of spacing and limiting methods. Spacing methods in developing country like India has been less in demand. Currently married women who are not using any method of contraception but who do not want any more children or want to wait two or more years before having another child are defined as having an unmet need for family planning. A society exhibiting norms of gender bias may show higher unmet need levels (Tauseef 1993).

According to the report of the first phase of NFHS, 19.5 percent of currently married women in India had an unmet need for both spacing and limiting births. This percent had come down during the next phase of the survey to 15.8 and again to 12.8 in the recent third phase of the survey.

Laya (2012) has found that 12.8 percent of the currently married women in India at present have an unmet need for family planning services, 6.2 percent for spacing and 6.6 percent for limiting based on National Family Health survey (2005). The percent of women having unmet need are much higher among those in the rural areas, at the younger ages and women having less than three children. Educational and working status of women is found to be highly significant with respect to their unmet need in India. Policies and programmes should be implemented to reach out to the rural illiterate poor married women so that they can avail the services easily and effectively without any barriers.
Radha Devi, Rastogi and Retherford (1996) found the unmet need for spacing was around 55 per cent while limiting around 89 per cent in Uttar Pradesh. Over the years family planning acceptance has increased, however, development seems to be a major indicator of acceptance of family planning. The present study makes an attempt to study unmet need in Uttar Pradesh at district level.

\section{Methodology}

District Level Health Survey 3 has been taken for analysis. Correspondence analysis (a form of factor analysis) of unmet need for spacing and limiting methods of family planning has been considered. This analysis gives a contingent tables and contribution of row wise (district) and column wise (unmet need for spacing and limiting) to each other. In addition the influence of wealth index and education to the unmet need has been planned. Bivariate logistic regressions at the state level and at district level Chandauli have been computed.

\section{Results and Discussion}

Unmet need for spacing:

One-tenth (10.07) of the State as a whole has an unmet need for spacing method of family planning. Two districts viz., Kanpur (3.11 per cent) and Gautam Buddha Nagar (4.45 per cent) have lowest unmet need for family planning.

Volume 5 Issue 6, June 2016 www.ijsr.net 


\section{International Journal of Science and Research (IJSR) \\ ISSN (Online): 2319-7064 \\ Index Copernicus Value (2013): 6.14 | Impact Factor (2015): 6.391}

Sultanpur, Bahraich, Sharwasti, Balarampur, Gonda and Siddarthanagar districts have largest need for spacing. There are two peaks of unmet need in the state: one group: Shahjahanpur, Kheri, Sitapur and Hardoi and the other:
Sultanpur, Bahraich, Sharwasti, Balarampur, Gonda and Siddarthanagar. Kanpur nagar (3.11) has the lowest demand for spacing methods in the state. (Table 1 and 2).

Table 1: Broad category of districts for unmet need for spacing methods of family planning

\begin{tabular}{|c|c|}
\hline Proportion spacing & Districts \\
\hline Below 5 (2) & Kanpur Nagar (3.11), Gautam Buddha Nagar (4.45), \\
\hline 5-10 (38 districts) & $\begin{array}{l}\text { Jalaun (5.04), Jhansi (5.21), Lalitpur (5.86), Ghaziabad (6.19), } \\
\text { Banda (6.3), Hathras (6.49), Meerut (6.71), Mahoba (6.73), Kanpur } \\
\text { Dehat (6.83), Saharanpur (6.89), Hamirpur (6.96), Chandauli (7.06), } \\
\text { (Baghpet (7.37), Deoria (7.45), Mainpuri (7.46), Unnao (7.76), } \\
\text { Bulandshahar (7.94), Ambedkar Nagar (8.23), Muzaffarnagar (8.24), } \\
\text { Rampur (8.39), Kushinagar (8.45), Auria (8.46), Sonbadra (8.47), } \\
\text { Bijnor (8.55), Maharajganj (8.55), Pilibhit (8.58), Bareilly (8.67), } \\
\text { Jyotiba Phule Nagar (8.76), Varanasi (8.96), Mathura (8.97), } \\
\text { Lucknow (9.14), Barabanki (9.33), Kannauj (9.45), Mirzapur (9.46), } \\
\text { Gorakhpur (9.6), Aligarh (9.65), Agra (9.92), Ballia (9.58) }\end{array}$ \\
\hline $10+(30)$ & $\begin{array}{l}\text { Moradabad (10.08), Basti (10.1), Allahabad (10.13), Mau (10.16), } \\
\text { Farrukhabad (10.23), Firozabad (10.24), Sant Kabir Nagar (10.27), } \\
\text { Etah (10.42), Chitrakoot (10.44), Pratapgarh (10.44), Jaunpur } \\
\text { (10.67), Etawah (10.97), Kaushambi (11.07), Hardoi (11.17), } \\
\text { Faizabad (11.4), Rae Bareilly (11.53), Gazipur (11.67), Sant Ravidas } \\
\text { Nagar (11.88), Sultanpur (12.38), Siddarthanagar (12.53), Fatehpur } \\
\text { (12.6), Budaun (13.1), Kheri (13.32), Shahjahanpur (14.04), } \\
\text { Azamgarh (14.11), Gonda (15.6), Sitapur (16.73), Bahraich (17.03), } \\
\text { Shrawasti (19.39), Balrampur (20.29) }\end{array}$ \\
\hline
\end{tabular}

Unmet need for spacing:

The total inertia (eigen values) has been $0.012 * 100=1.2$ per cent only.
The correspondence analysis reflects that the correlation between region/districts and unmet need, while significant, was weak. Of the total inertia majorly Sitapur (0.001), Kanpur Nagar (0.001), Bahraich (0.001), Shrawasti (0.002), Balarampur (0.002) have contributed to unmet need for spacing totalling 0.012 .

Table 2: Summary for spacing methods

\begin{tabular}{|c|c|c|c|c|c|c|c|}
\hline \multirow{2}{*}{$\begin{array}{c}\text { Dimensio } \\
n\end{array}$} & \multirow{2}{*}{ Singular Value } & \multirow{2}{*}{ Inertia } & \multirow{2}{*}{ Chi Square } & \multirow{2}{*}{ Sig. } & \multicolumn{2}{|c|}{ Proportion of Inertia } & \multirow{2}{*}{\begin{tabular}{|c|}
$\begin{array}{c}\text { Confidence } \\
\text { Singular Value }\end{array}$ \\
Standard Deviation
\end{tabular}} \\
\hline & & & & & Accounted for & Cumulative & \\
\hline 1 & .108 & .012 & & & 1.000 & 1.000 & .004 \\
\hline Total & & .012 & 1022.597 & $.000^{\mathrm{a}}$ & 1.000 & 1.000 & \\
\hline \multicolumn{3}{|c|}{ a. 69 degrees of freedom } & & & & & \\
\hline
\end{tabular}

Unmet need for spacing:

The total inertia for the columns was 0.011 and 0.001 for yes and no categories respectively.

\begin{tabular}{|c|c|c|c|c|c|c|}
\hline \multirow{3}{*}{$\begin{array}{c}\text { unmet need of } \\
\text { spacing method } \\
\text { (as DLHS-2) }\end{array}$} & \multirow{3}{*}{ Mass } & \multirow{3}{*}{$\begin{array}{c}\text { Score in } \\
\text { Dimension } \\
1\end{array}$} & \multirow{3}{*}{ Inertia } & \multicolumn{3}{|c|}{ Contribution } \\
\hline & & & & \multirow{2}{*}{$\begin{array}{c}\text { Of Point to Inertia } \\
\text { of Dimension }\end{array}$} & \multicolumn{2}{|c|}{ Of Dimension to Inertia of Point } \\
\hline & & & & & 1 & Total \\
\hline Yes & .101 & .983 & .011 & .899 & 1.000 & 1.000 \\
\hline No & .899 & -.110 & .001 & .101 & 1.000 & 1.000 \\
\hline Active Total & 1.000 & & .012 & 1.000 & & \\
\hline \multicolumn{3}{|c|}{ a. Symmetrical normalization } & & & & \\
\hline
\end{tabular}

Transformed district categories:

There were several peaks of unmet need for spacing. The first small peak appears at Moradabad district.
The low point starts from Saharanpur district, Muzaffarnagar, Bijnor and Moradabad and reaching Moradabad. The need declines from Rampur,Jyotiba phule nagar, Meerut, Bhagpet, Ghaziabad, and Gautam Buddha nagar. A part of Guatam Buddha nagar includes NOIDA

Volume 5 Issue 6, June 2016 www.ijsr.net 


\section{International Journal of Science and Research (IJSR) \\ ISSN (Online): 2319-7064 \\ Index Copernicus Value (2013): 6.14 | Impact Factor (2015): 6.391}

(New Okhla Industrial Development Area), a part of National Capital Region, New Delhi. Guatam Buddha Nagar district might have been benefitted by adjacent New Delhi. Similarly Mathura and Hathras districts might have great influence from New Delhi with low unmet need for spacing. Another district worth mentioning is Mainpuri showing low unmet need. It is surrounded by high unmet need districts: Frozabad, Etah, Etawah, Farrukhabad, Hardoi, and Kannauj.

\section{Dimension 1 Transformed district Categories}

Symmetrical Normalization

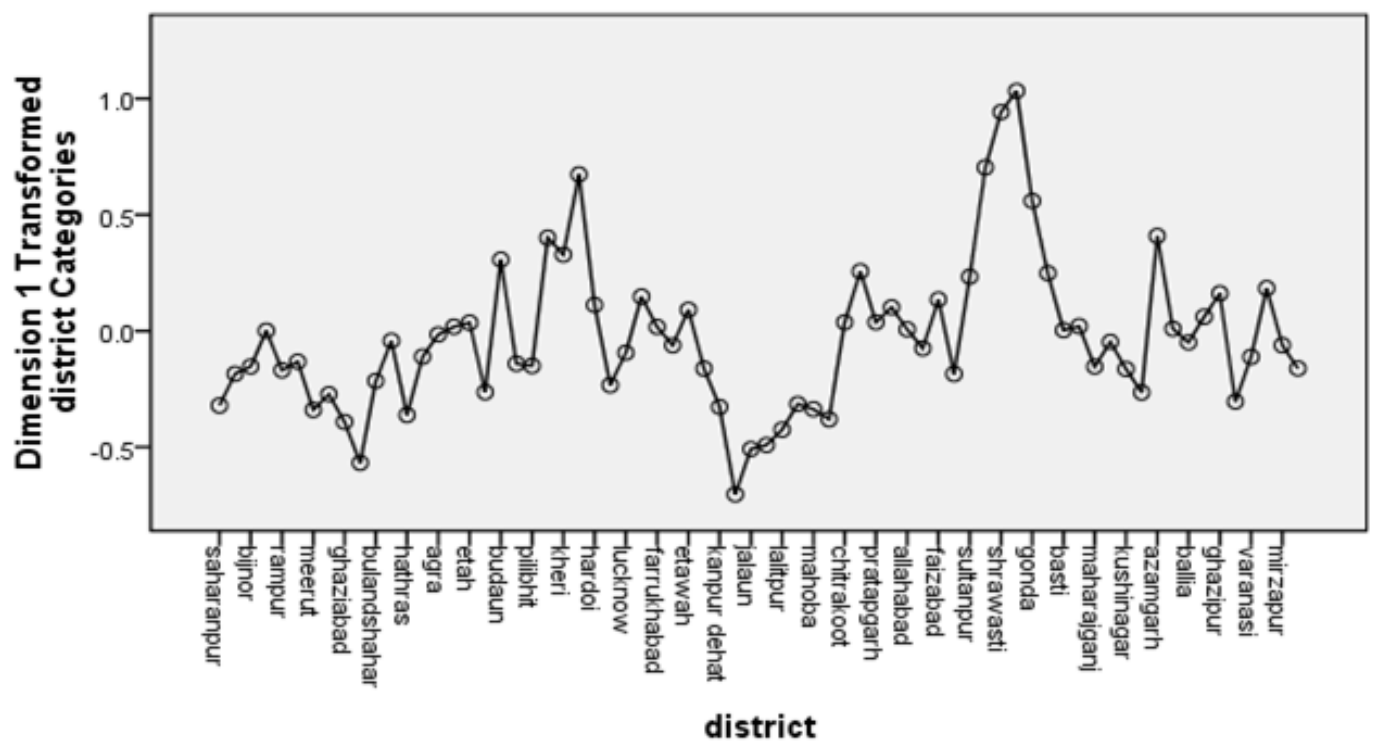

Figure 1: Spacing method

\section{Dimension 1 Transformed unmet need of spacing method (as DLHS-2) Categories}

\section{Symmetrical Normalization}

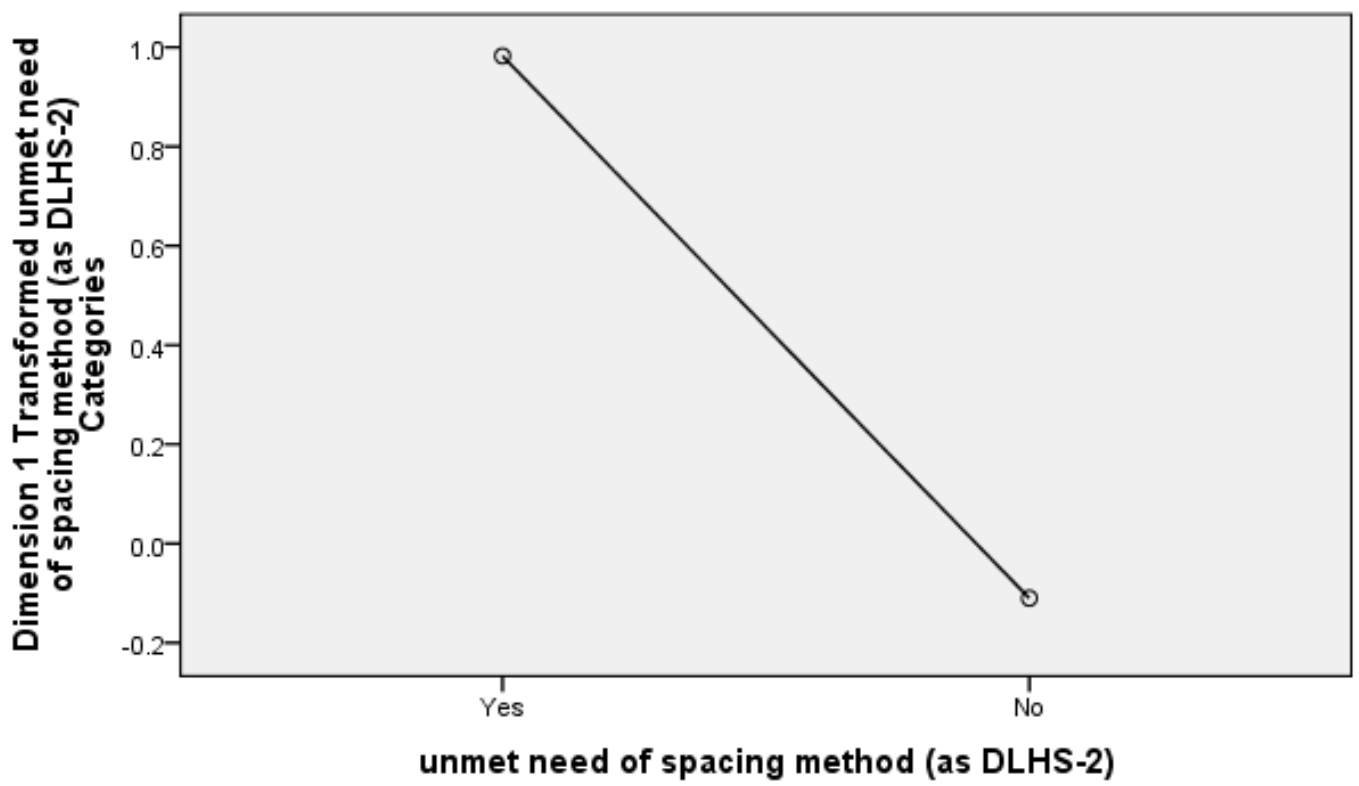

Figure 2: Spacing method wise

Unmet need for limiting family size:

Unmet need for limiting family size has been given according to per cent of requirement. Only 3 districts have below 10 per cent of need. On the other extreme Budaun
(31.23 per cent) and Ferozabad (33.49 per cent) have high unmet need for limiting methods. (Table 4, 5)

\section{Volume 5 Issue 6, June 2016} www.ijsr.net 
International Journal of Science and Research (IJSR)

ISSN (Online): 2319-7064

Index Copernicus Value (2013): 6.14 | Impact Factor (2015): 6.391

Table 4: Unmet need for limiting

\begin{tabular}{|c|c|}
\hline Value (Per cent) & Districts \\
\hline Below 10 (3 districts) & Jhansi (7.31), Varanasi (8.8) and Sonbhadra (9.7) \\
\hline 10-15 (7 districts) & $\begin{array}{l}\text { Lalitpur (10.54), Meerut (11.28), Jalaun (11.66). Mahoba (13.56), } \\
\text { Hamirpur (14.17), Gautam Buddha Nagar (14.89), Ghaziabad } \\
\text { (14.96),, }\end{array}$ \\
\hline 15-20 (19 districts) & $\begin{array}{l}\text { Saharanpur (15.26), Banda (15.75), Allahabad (16.32), Chitrakoot } \\
\text { (16.43), Faizabad (17.15), Kanpur Dehat (17.17), Kanpur Nagar } \\
\text { (17.44), Ballia (17.52), Gorakhpur (17.77), Sant Ravidas Nagar } \\
\text { (18.23), Maharajganj (18.32), Chandauli (18.71), Baghpet (18.82), } \\
\text { Ambedaker nagar (18.95), Barabanki (19.16), Kaushambi (19.55), } \\
\text { Bijnor (19.85), Jaunpur (19.95) }\end{array}$ \\
\hline 20-25 (32 districts) & $\begin{array}{l}\text { Kheri (20.11), Sultanpur (20.44), Bulandshahar } \text { (20.71), } \\
\text { Siddarthanagar (20.72), Hathras (20.86), Rampur (20.88), Mau (21), } \\
\text { Lucknow (21.03), Basti (21.03), Pilibhit (21.12), Jyotiba Phule } \\
\text { Nagar (21.25), Ghazipur (21.8), Kushinagar (21.83), Azamgarh } \\
\text { (21.92), Rae Bareli (22), Unnao (22.31), Sitapur (22.49), Pratapgarh } \\
\text { (22.84), Shrawasti (23.1), Muzaffarnagar (23.23), Sant Kabir Nagar } \\
\text { (23.29), Mainpuri (23.33), Bareilly (23.47), Kannauj (23.53), } \\
\text { Moradabad (24.11), Farrukhabad (24.19), Shahjahanpur } \\
\text { Deoria (24.25), } \\
\text { (24.75), Mathura (24.93), }\end{array}$ \\
\hline $25+$ (9 districts) & $\begin{array}{l}\text { Fatehpur (25.48), Hardoi (26.25), Auraiya (26.35), Balrampur } \\
\text { (26.55), Etawah (27.08), Agra (28.63), Etah (29.5), Budaun (31.23), } \\
\text { Ferozabad (33.49) }\end{array}$ \\
\hline
\end{tabular}

Unmet need for limiting:

The total inertia (eigen values) has been $0.016 * 100=1.6$ per cent only. The correspondence analysis reflects that the correlation between region/districts and unmet need, while significant, was weak.
Meerut, Etah, Budaun, Jalaun, Jhansi, Lalitpur, Varanasi, Mirzapur and Sonbhadra each contributed (0.001) and Firozabad contributed (0.002) totalling 0.016 for limiting methods. The column wise values reveal 1.3 per cent for unmet need and .03 per cent for no need. (Table 6,7 ).

Table 6: Summary table

\begin{tabular}{|c|c|c|c|c|c|c|c|}
\hline \multirow{2}{*}{ Dimension } & \multirow{2}{*}{ Singular Value } & Inertia & Chi Square & \multirow{2}{*}{ Sig. } & \multicolumn{2}{|c|}{ Proportion of Inertia } & $\begin{array}{c}\text { Confidence Singular } \\
\text { Value }\end{array}$ \\
\cline { 5 - 8 } & & & & & Accounted for & Cumulative & Standard Deviation \\
1 & .127 & .016 & & & 1.000 & 1.000 & .003 \\
\hline Total & .016 & 1404.030 & $.000^{\mathrm{a}}$ & 1.000 & 1.000 & \\
\hline
\end{tabular}

Table 7: Overview Column Points ${ }^{\mathrm{a}}$

\begin{tabular}{|c|c|c|c|c|c|c|}
\hline \multirow{3}{*}{$\begin{array}{l}\text { unmet need of } \\
\text { limiting method } \\
\text { (as DLHS-2) }\end{array}$} & \multirow{3}{*}{ Mass } & \multirow{3}{*}{$\begin{array}{c}\text { Score in Dimension } \\
1\end{array}$} & \multirow{3}{*}{ Inertia } & \multicolumn{3}{|c|}{ Contribution } \\
\hline & & & & \multirow{2}{*}{$\begin{array}{c}\text { Of Point to Inertia of } \\
\text { Dimension }\end{array}$} & \multicolumn{2}{|c|}{ Of Dimension to Inertia of Poin } \\
\hline & & & & & 1 & Total \\
\hline Yes & .206 & .698 & .013 & .794 & 1.000 & 1.000 \\
\hline No & .794 & -.181 & .003 & .206 & 1.000 & 1.000 \\
\hline Active Total & 1.000 & & .016 & 1.000 & & \\
\hline \multicolumn{3}{|c|}{ a. Symmetrical normalization } & & & & \\
\hline
\end{tabular}

\section{Volume 5 Issue 6, June 2016 www.ijsr.net}


Transformed district categories:

The following graph shows the several peaks of unmet need for limiting.

\section{Dimension 1 Transformed district Categories \\ Symmetrical Normalization}

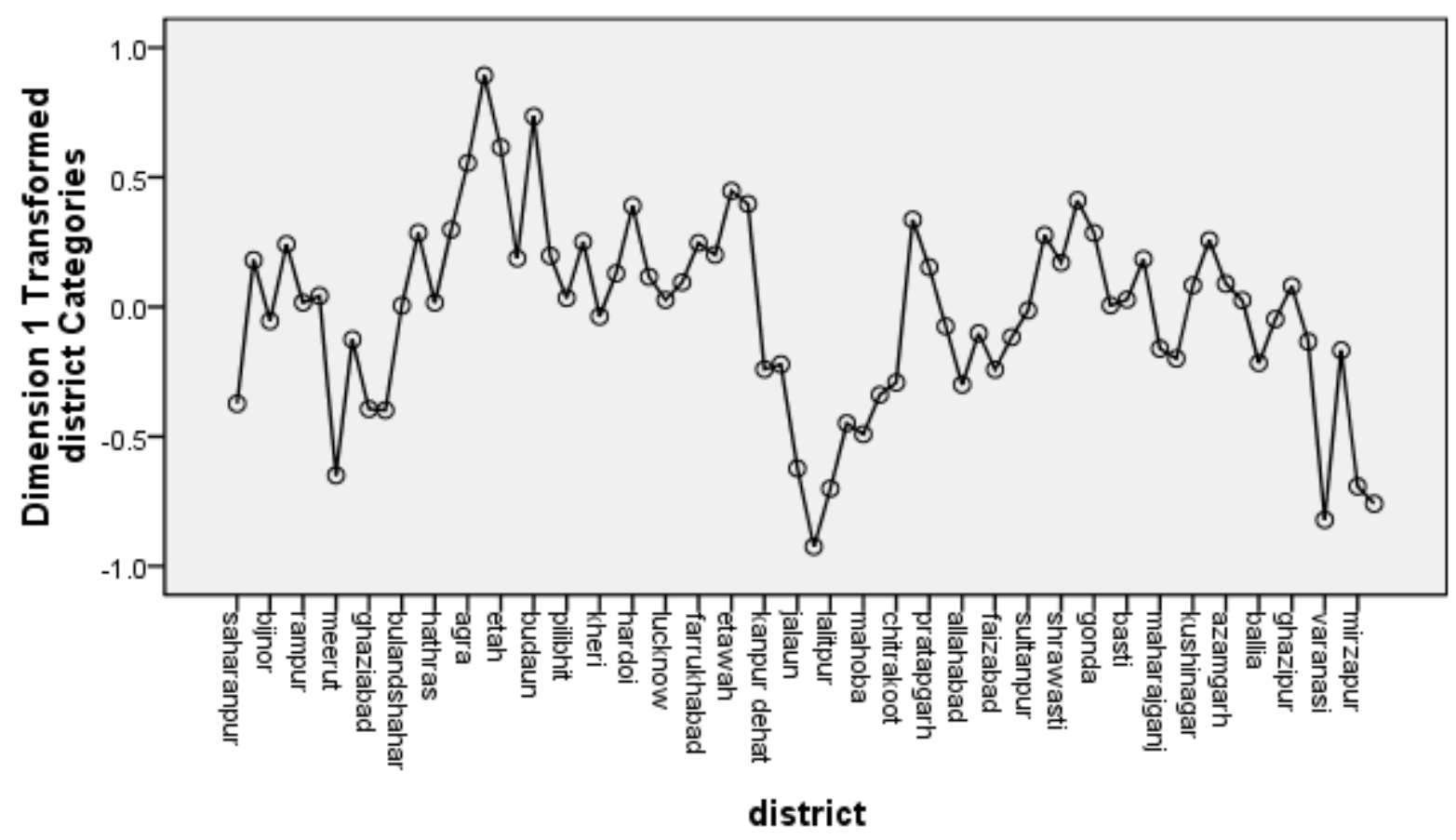

\section{Dimension 1 Transformed unmet need of limiting method (as DLHS-2) Categories}

\section{Symmetrical Normalization}

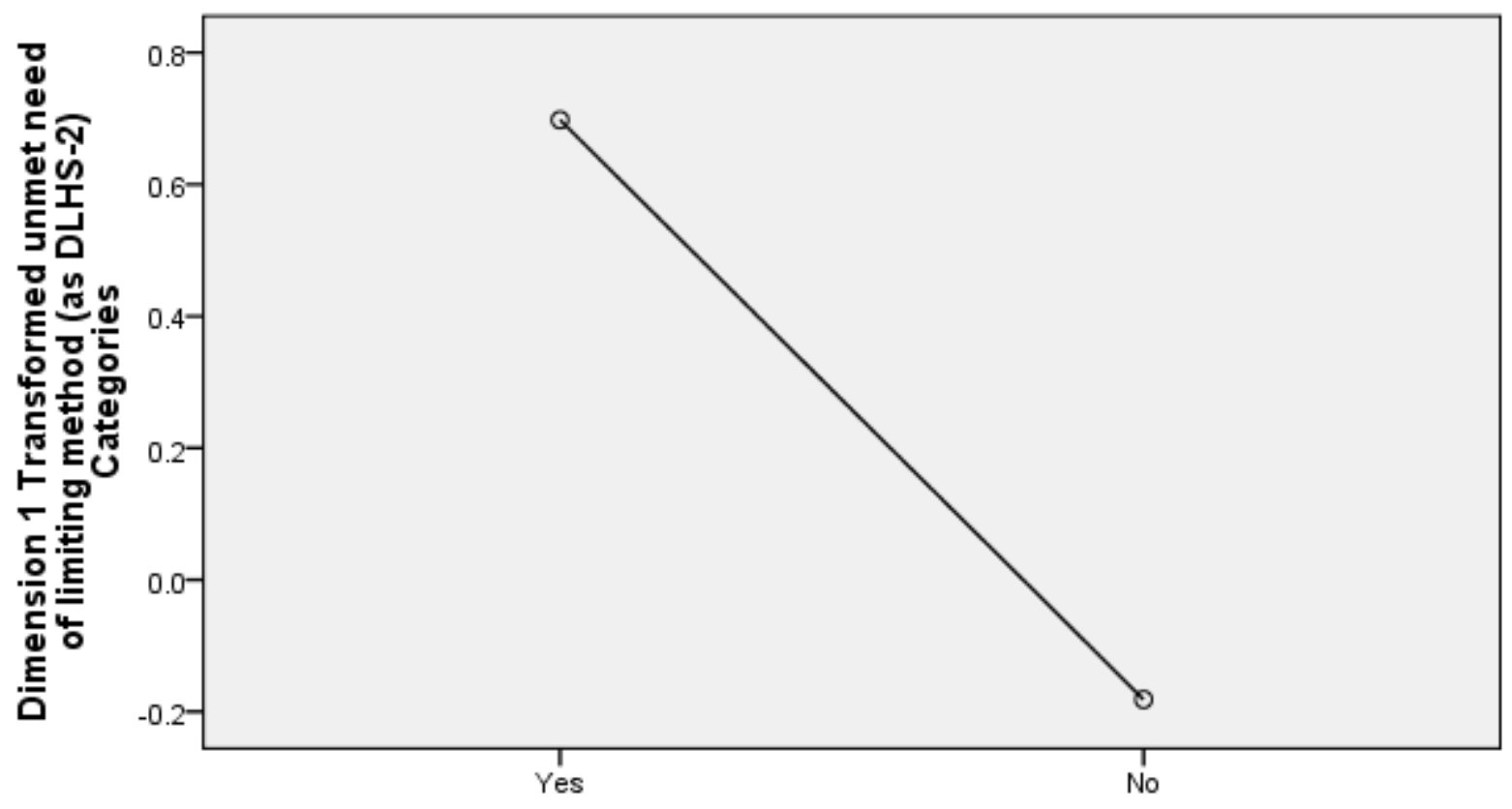

unmet need of limiting method (as DLHS-2)

Of the total inertia majorly Sitapur (0.001), Kanpur Nagar (0.001), Bahraich (0.001), Shrawasti (0.002), Balarampur (0.002) have contributed to unmet need for limiting totalling 0.012 whereas Meerut, Etah, Budaun, Jalaun,
Jhansi, Lalitpur, Varanasi, Mirzapur and Sonbhadra each contributed (0.001) and Firozabad (0.002) totalling 0.016 for limiting methods.

Volume 5 Issue 6, June 2016 www.ijsr.net 


\section{International Journal of Science and Research (IJSR) \\ ISSN (Online): 2319-7064 \\ Index Copernicus Value (2013): 6.14 | Impact Factor (2015): 6.391}

Unmet need for spacing and limiting family size in relation to outcome for the last pregnancy:

This table reveals that 12.1 per cent $(10555 / 87564 * 100)$ need spacing methods. Women with no loss children constitute major portion followed by spontaneous abortion, induced abortion and still births. Around 95 per cent who were in need of spacing methods of family planning desire spacing methods after having live births. A similar proportion of respondents (97.45 per cent) with live births desired limiting methods of family planning. Around 2 per cent of respondents with the experience of induced/spontaneous abortion desired spacing methods. Around one percent of respondents with spontaneous abortion desire to have limiting methods of family planning.

Table 8: Outcome of Pregnancy in relation to unmet need for limiting and spacing methods of family planning

\begin{tabular}{|c|c|c|c|c|}
\hline Unmet need for limiting & Outcome of Pregnancy & Unmet need of spacing & total \\
\hline & & Yes & No & \\
\hline Yes & Live birth & & $95(10027)$ & 10027 \\
\hline & Still birth & & $0.9(95)$ & 95 \\
\hline & Induced abortion & & $1.99(210)$ & 210 \\
\hline & Spontaneous abortion & & $2.11(223)$ & 223 \\
\hline & Total & & $100(10555)$ & 10555 \\
\hline Lo & Live birth & $97.45(7265)$ & 20394 & 27659 \\
\hline & Still birth & $0.47(35)$ & 403 & 438 \\
\hline & Induced abortion & $0.46(34)$ & 662 & 696 \\
\hline & Spontaneous abortion & $1.62(121)$ & 1405 & 1526 \\
\hline & Total & $100(7455)$ & 22864 & 30319 \\
\hline
\end{tabular}

Type of family planning method used:

Around two-fifths (36.5 per cent: $31943 / 87564 * 100)$ were using some method of family planning. Among them around half (45.9 per cent) have underwent sterilization.
Remaining half were using different methods of temporary contraception. Rhythm and condom/nirodh were the major ones. Sterilizations constitute only 16.75 per cent $(14665 / 87564 * 100)$ for the total population.

Table 9: Number and per cent use of family planning methods

\begin{tabular}{|l|c|}
\hline Type of family planning method used & Per cent and Number \\
\hline Female sterilization & $45.4(14497)$ \\
\hline Male sterilization & $0.5(168)$ \\
\hline IUD & $2.6(822)$ \\
\hline Daily pills & $3.4(1077)$ \\
\hline Weekly pills & $0.8(264)$ \\
\hline Injectables & $0.5(156)$ \\
\hline Condom/Nirodh & $17.4(5565)$ \\
\hline Female condom & $0(11)$ \\
\hline Rhythm method & $23.5(7503)$ \\
\hline Withdrawal & $5.2(1656)$ \\
\hline Other & $0.7(224)$ \\
\hline Total & $100.0(31943)$ \\
\hline
\end{tabular}

Logistic Regression:

This analysis has been made for the whole state. There were some differences when it came to the determinants of spacing and limiting methods. It may be due to two different age groups of women practicing these methods. Spacing mostly has been followed by younger women and the limiting methods by older cohort of women or women who have completed their family size.
Respondents' years of schooling, respondent age at first birth (not significant) and number of live births were positively correlated with spacing methods whereas it was negative in the case of limiting methods. However, wealth index was positively correlated with spacing and limiting (at rich level) methods. Semi-pucca house was correlation positively with spacing and negatively with spacing methods. 
International Journal of Science and Research (IJSR)

ISSN (Online): 2319-7064

Index Copernicus Value (2013): 6.14 | Impact Factor (2015): 6.391

Logistic regression:

\begin{tabular}{|c|c|c|c|c|}
\hline Variable & Spacing & Significance & Limiting & Significance \\
\hline $\begin{array}{c}\text { Respondents' years of } \\
\text { schooling }\end{array}$ & 1.011 & .048 & .987 & .008 \\
\hline Respondents' age at birth & 1.008 & .228 & .997 & .635 \\
\hline Live births & 1.687 & .000 & .745 & .000 \\
\hline Wealth Index (Poor) & & & & .130 \\
\hline Moderate & 1.261 & .000 & 1.079 & .000 \\
\hline Rich & 1.537 & & & .000 \\
\hline Had BPL card (No) & & .428 & & .000 \\
\hline No & .962 & & .000 & .974 \\
\hline Type of house (kutcha) & 1.181 & .730 & 15.517 & .911 \\
\hline Semi-pucca & .919 & .009 & 27491.158 & .000 \\
\hline Pucca & 1.340 & & & \\
\hline Constant & 21083.685 & & & \\
\hline-2 log likelihood & & &
\end{tabular}

Logistic regression for Chandauli district:

Spacing methods was followed by women with number of children, not having a Below Poverty Line card, and high wealth index and limiting was otherwise.

\begin{tabular}{|c|c|c|c|c|}
\hline Variable & Spacing & Significance & Limiting & Significance \\
\hline $\begin{array}{c}\text { Respondents' years of } \\
\text { schooling }\end{array}$ & .959 & .453 & .955 & .240 \\
\hline Respondents' age at birth & .902 & .061 & .998 & .791 \\
\hline Live births & 1.885 & .000 & & .960 \\
\hline Wealth Index (Poor) & & & .840 & .000 \\
\hline Moderate & 3.123 & .053 & .807 & .694 \\
\hline Rich & 2.842 & & .980 & .953 \\
\hline Had BPL card (Yes) & & .041 & & \\
\hline No & 2.350 & .522 & .540 & .138 \\
\hline Type of House (Kutcha) & .908 & .999 & .000269 & .999 \\
\hline Semi-pucca & .000121 & .094 & 9.575 & .002 \\
\hline Pucca & 4.656 & & 442.564 & \\
\hline Constant & 247.322 & & & \\
\hline
\end{tabular}

\section{Conclusion and Recommendations}

Unmet need for contraception varies from district to district based on development namely wealth index. Some districts near to national capital had more unmet need for spacing and Limiting at rich category of wealth index and some districts with less development had shown at poor category. It means that most of the households in these districts either belonged to rich or poor category. Moderate level of wealth index was second highest either in the case of poor/rich highest. Meerut and Ghaziabad districts (spacing) and Ghaziabad (limiting) had highest (above 75 per cent) unmet need in the state as a whole. We have 12 and 10 districts in the category of 50-75 percent respectively for spacing and limiting.
Highest proportion of districts were listed with 25-50 per cent category for spacing (39) and limiting (36) needs followed by below 25 per cent.

In general respondents of some districts, belonged equally to either poor or rich categories for spacing (Chandauli : 43.4 for both), Azamgarh (poor: 33.5 and rich: 36.7), Allahabad (poor: 40.3 and rich: 37 ) and Etah (poor: 36 and poor : 35.2)and limiting methods (Etawah (poor: 36.4 and rich: 38.9), Allahabad (poor: 39.1 and rich: 41.1), Gorakhpur (poor: 41.9 and rich: 39.1) and Chaundali (poor: 42.7 and rich: 38.2). Chandauli district was carved out of Varanasi division is agriculturally developed district and aptly called 'Dhaan Ka Katora of Uttar Pradesh. All the other districts have their own importance having population rich and poor alike. 


\section{International Journal of Science and Research (IJSR) \\ ISSN (Online): 2319-7064}

Index Copernicus Value (2013): 6.14 | Impact Factor (2015): 6.391

Table 10: Wealth index in relation to unmet need for spacing and limiting methods in the districts of Uttar Pradesh

\begin{tabular}{|c|c|c|c|c|}
\hline & & Spacing & & Limiting \\
\hline \multicolumn{5}{|l|}{ Wealth index (Rich) } \\
\hline Above 75 per cent $(2)$ & 2 & Meerut (83.3), Gaziabad (81.8) & 1 & Ghaziabad (80.6), \\
\hline $50-75$ per cent $(12)$ & 12 & $\begin{array}{l}\text { Jyotiba Phule nagar } \text { (52.5),Bulandshahar } \\
\text { (53.3),Lucknow (53.4), Aligarh (55.7), Mathura } \\
\text { (55.8), Agra (57.7), Kanpur Nagar (61.5), Bijnor } \\
\text { (64.2), Saharanpur (64.3), Baghpat } \\
\text { (66),Muzaffarnagar (70.5), Gautam Buddha Nagar } \\
\text { (76.1) }\end{array}$ & 10 & $\begin{array}{l}\text { Saharanpur (53.5),Bijnor (53.7), Varanasi } \\
\text { (54.1), Agra (54.6), Mathura (56.4), } \\
\text { Muzaffarnagar (61.8), Baghpat (66.7), } \\
\text { Gautam Buddha Nagar (68.8), } \\
\text { Meerut (72.1), }\end{array}$ \\
\hline $25-50$ per cent (39) & 39 & $\begin{array}{l}\text { Kaushambi (25.3), Maharajganj (27), Mahoba } \\
\text { (27.5), Hamirpur (28.3), Philibhit (28.6), Banda } \\
\text { (29.5), Sultanpur (30.3), Faizabad (30.6). } \\
\text { Kushinagar (30.9),Basti (32.1), Ambedkar Nagar } \\
\text { (32.3), Unnao (33.3), Sant Kabir nagar (33.3), } \\
\text { Ghazipur (34.2), Auraiya (35.1), Etah (35.2), } \\
\text { Kanpur Dehat (35.7), Azamgarh (36.7), Allahabad } \\
\text { (37), Pratapgarh (37.6), Ballia (37.8), Mirzapur } \\
\text { (37.3), Mainpuri (39.3), Sant Ravi Das Nagar } \\
\text { (40.4), Bareilly (41.3),Etawah (42.2), Chandauli } \\
\text { (43.4), Rampur (43.6),Gorakhpur (49.3), Firozabad } \\
\text { (45.4), Varanasi (45.1), Jhansi (46.2),Hathras (46.7), } \\
\text { Mau (47.5), Moradabad (47.6), Jalaun (48.1), } \\
\text { Deoria (50), Jaunpur (50) }\end{array}$ & 36 & $\begin{array}{l}\text { Kaushambi (26.5), Mainpuri (27.3), Rae } \\
\text { Bareilly, Faizabad (28), Maharajganj } \\
\text { (28.5), Etah (28.8), Pratapgarh (30.5), } \\
\text { Ghazipur (31), Pilibhit (31.1), Sultanpur } \\
\text { (32.2), Hamirpur (32.4), Azamgarh } \\
\text { (32.5), Deoria (32.8), Bareilly (33.1), } \\
\text { Basti (33.4), Ambedkar Nagar (33.9), } \\
\text { Mau (35.5), Sant Ravidas Nagar } \\
\text { (36.1), Rampur (37.1), Mirzapur (37.3), } \\
\text { Chandauli (38.2), Jaunpur (38.3), Etawah } \\
\text { (38.9), Gorakhpur (39.1), Allahabad } \\
\text { (41.1), Firozabad (42.1), Moradabad, } \\
\text { Jalaun (43.2), Hathras (46.6), } \\
\text { Bulandshahar (47.9), Jyotiba Phule Nagar } \\
\text { (49), Aligarh (49.5), Kanpur Nagar (56.2), } \\
\text { Jhansi (57.5), Lucknow (59.5), }\end{array}$ \\
\hline Below 25 per cent $(18)$ & 18 & $\begin{array}{l}\text { Bahraiach (8.2), Shrawasti (11.6), } \text { Hardoi } \\
\text { (12.3),Sitapur (13.8), Kheri (14.4), Chitrakoot } \\
\text { (14.9), Fatehpur (15.9), Sonbhadra (16.7), } \\
\text { Balarampur (18.5), Budaun (19.4), Gonda }(20.4) \text {, } \\
\text { Shahjahanpur (20.8), Kannuj (21.5), Farrukhabad } \\
\text { (21.7), Siddarthanagar (22), Barabanki (22.5), } \\
\text { Lalitpur (23.2), Rae Bareilly (24.6) }\end{array}$ & 26 & $\begin{array}{l}\text { Shrawasti (14.4), Sitapur (15.1), Kheri } \\
\text { (17.7), Balarampur (18.2), Budaun (18.4), } \\
\text { Banda (18.5), Bahraich (18.9), Chitrakoot } \\
\text { (19), Hardoi, Siddarthanagar, (20.6), } \\
\text { Shahjahnpur (20.9), Kanpur Dehat (21), } \\
\text { Gonda (21.6), Kannauj (21.7), Lalitpur, } \\
\text { Sonbhadra (21.8), Fatehpur (22.2), Unnao } \\
\text { (22.7), Ballia (23.2), Sant Kabir nagar } \\
\text { (23.6), Kushinagar (23.9), Barabanki } \\
\text { (24.1), Farrukhabad (24.3), Mahoba } \\
\text { (24.5), Auraiya (24.8), }\end{array}$ \\
\hline Wealth Index (Poor) & & Districts & & Districts \\
\hline Above 75 per cent & & Bahraich (79.3) & & \\
\hline $50-75$ per cent & & $\begin{array}{l}\text { Basti (50), Barabanki (50.5), Kushinagar (52.1), Rae } \\
\text { Bareilly (52.8), Siddarthnagar(53.3), Faizabad } \\
\text { (53.7), Ambedkarnagar (54.2), Kaushambi (55.1), } \\
\text { Shahjahanpur (57.4), Farrukhabad (58.6), Budaun } \\
\text { (60.7), Chitrakoot (61.2), Gonda (61.9), Balarampur } \\
\text { (62.3), Kheri (62.4), Sonbhadra (65.6), Fatehpur } \\
\text { (65.9), Hardoi (67.5), Sitapur (71.7), Shrawasti } \\
\text { (73.3), }\end{array}$ & & $\begin{array}{l}\text { Rae Bareilly (50.6), Kannauj (50.9), } \\
\text { Mainpuri (51.6), Ballia (51.7), Etah (52), } \\
\text { Maharajganj (53), Farrukhabad (53.1), } \\
\text { Kanpur Kaushambi, } \\
\text { Ambedkarnagar (53.4), Unnao (53.6), } \\
\text { Kushinagar (53.9), Fatehpur (54.1), } \\
\text { Barabanki (54.8), Chitrakoot, Sant Kabir } \\
\text { Nagar (55), Siddharthnagar (55.1), Banda } \\
\text { (55.4), Faizabad (56), Lalitpur (58.1), } \\
\text { Shahjahnpur (58.5), Budaun (61.4), } \\
\text { Gonda (62), Hardoi (62.7), Sonbhadra } \\
\text { (63.6) Kheri (65.9), Balrampur (69.1), } \\
\text { Sitapur (69.3), Bahraich (70.5), Shrawasti } \\
\text { (72.6) }\end{array}$ \\
\hline
\end{tabular}

Wealth index influences unmet need which invariably is linked to education. Unmet need depends on availability, affordability and acceptability of contraceptives. Hence efforts were to be made in this direction. Unmet need exists due to several reasons. Spacing has been main casualty. Women still are not still convinced about the efficacy of spacing methods and also difficulty to maintain spacing methods. Terminal methods too are not properly favoured due to personal causes. Lot of persuasion is the need of the hour with benefits accruing out of following family planning methods.

\section{References}

[1] Laya K S 2012. Prevalence of and Determinants of Unmet Need for Family Planning among Women in India. Research and Social Practices in Social Sciences 7 (2): 59-70

[2] National Consultation of Civil Organizations on Family Planning. A Concept Note 2012 New Delhi: India International Centre (IIC)

[3] Radha Devi D., S R Rastogi and R D Retherford 1996 Unmet Need for Family Planning In Uttar Pradesh

[4] National Family Health Survey Reports Number 1 Mumbai: International Institute for Population Sciences

[5] Tauseef Ahmed 1993 Unmet need for Contraception in Pakistan: Pattern and Determinants

[6] Demography India 22 (1): 31-51

\section{Volume 5 Issue 6, June 2016} www.ijsr.net 